\title{
Modified GDP Through Health Cost Analysis of Air Pollution: The Case of Turkey
}

\author{
KATALIN KOVARI ZAIM \\ Department of Computer Technology and Office \\ Management \\ Bilkent University \\ 06533-Bilkent, Ankara, Turkey
}

ABSTRACT / Economic growth and performance is monitored through the gross domestic product (GDP) of a nation. It has long been recognized that the traditionally computed GDP does not account for gains and losses observed due to the consumption of natural resources and environmental services. Hence, the objective of this study is to modify the Turkish GDP by taking social cost associated with air pollution into consideration. To this end health benefits and economic costs of air-quality improvement are estimated. The computations are based on the dose-response coefficients reported in several studies. The results indicate that a decrease in $\mathrm{PM}_{10}$ and $\mathrm{SO}_{2}$ levels to the $\mathrm{WHO}$ guideline would have resulted in a total of $48.309 \times 10^{10}$ and $153.38 \times 10^{10}$ Turkish lira savings in 1990 and 1993, respectively. These correspond to $0.12 \%$ and $0.08 \%$ of 1990 and 1993 GDPs, respectively.
Economic production of any commodity uses natural resources as inputs, which are then transformed into human-produced goods and services. Economic activity requires both the use of human capital as well as the support of ecosystems. H uman-made capital cannot be created and sustained without natural resources. There will al ways be a minimum or critical amount of natural capital needed to sustain economic production and human survival. The life-support environment is that part of the earth that provides the biophysical necessities of life, namely food, air, and water (Berkes and Folke 1992). The structure and processes of the ecosystem have to be intact and functioning in order to support the continuous production of renewable natural capital. Therefore, any deteriorating effect on the ecosystem should be accounted for in the economic performance measurement.

A national economic accounting system such as gross domestic product (GDP) records monetary flows and transactions within the economy. The GDP figure is used as an indicator of well-being (development) of a nation. I ts objective is to record economic activities, but not to measure aggregated well-being. The aggregate well-being includes not only the gains and losses from economic activities but also from natural resources and ecological services.

Environmental damage generates costs that are not currently recorded as part of GDP, but which would be if GDP accounts were modified to reflect comprehensive measures of aggregated well-being together with the economic activity. Such an adjustment in the GDP computation is crucial while assessing the well-being of

KEY WORDS: Health costs; Air pollution; Modified GDP a nation. The objective of this study is to modify the GDP through estimated health costs associated with air pollution.

\section{Modifying the National Accounts}

As Pearce (1993) points out, material and energy flows begin at the point of extraction, harvest or use of natural resources. They end by being waste products, i.e., emissions to ambient environments, discharges to water, and solid waste to land or sea. Logically, then, GDP needs to be modified to account for any depreciation of natural capital stocks and for any damage losses accruing to human well-being from the extraction, processing, and disposal of materials and energy to receiving environments (Pearce 1993). O ne proposed method of GDP adjustment is as follows ( L utz 1993) :

$$
E D P=G D P-D_{k}-D_{n}
$$

where EDP is the ecodomestic product, $D_{k}$ is the depreciation on man-made capital (machines, roads, buildings, etc.), and $D_{n}$ is the depreciation of environmental assets. The valuation methods of depreciation of environmental assets depend on the specific case. In this study the health and economic benefits of reducing particulate matter $\left(\mathrm{PM}_{10}\right)$ and $\mathrm{SO}_{2}$ levels to the WHO guideline in major towns in Turkey in 1990 and 1993 are estimated. The computed values are deducted from the 1990 and 1993 GDPs to account for the social costs.

\section{Urban Air Pollution in the Major Cities of Turkey}

According the Turkish State Statistic Department's report, the most populated cities in 1990 are Ankara, 
Table 1. Population and number of industries in major cities of Turkey

\begin{tabular}{|c|c|c|c|c|c|c|c|}
\hline & \multicolumn{2}{|c|}{ Total population $\left(\times 10^{6}\right)$} & \multicolumn{2}{|c|}{ Employed age 12 and above $\left(\times 10^{6}\right)$} & \multicolumn{2}{|c|}{ Child age $0-12\left(\times 10^{6}\right)$} & \multirow{2}{*}{$\begin{array}{c}1990 \text { industries } \\
(\%)\end{array}$} \\
\hline & 1990 & 1993 & 1990 & 1993 & 1990 & 1993 & \\
\hline Ankara & 2.84 & 3.25 & 1.10 & 1.22 & 0.56 & 0.65 & 4.30 \\
\hline Bursa & 1.16 & 1.21 & 0.66 & 0.76 & 0.34 & 0.39 & 5.26 \\
\hline Erzurum & 0.40 & 0.45 & 0.17 & 0.19 & 0.21 & 0.24 & 1.40 \\
\hline Istanbul & 6.75 & 7.77 & 2.54 & 2.90 & 1.01 & 1.17 & 42.35 \\
\hline Izmir & 2.13 & 2.46 & 1.08 & 1.24 & 0.45 & 0.52 & 10.10 \\
\hline Kayseri & 0.60 & 0.70 & 0.34 & 0.40 & 0.21 & 0.24 & 1.28 \\
\hline Sivas & 0.38 & 0.46 & 0.16 & 0.18 & 0.19 & 0.23 & 0.20 \\
\hline Others & 42.31 & 43.27 & - & - & - & - & 35.11 \\
\hline Total & 56.57 & 59.87 & - & - & - & - & 100 \\
\hline
\end{tabular}

Source: SYT (1994).

Table 2. Annual average $\mathrm{SO}_{2}$ and $\mathrm{PM}_{10}$ ambient concentrations $\left(\mu \mathrm{g} / \mathrm{m}^{3}\right)$

\begin{tabular}{|c|c|c|c|c|c|c|c|c|}
\hline & \multicolumn{2}{|c|}{1990} & \multicolumn{2}{|c|}{1991} & \multicolumn{2}{|c|}{1992} & \multicolumn{2}{|c|}{1993} \\
\hline & $\mathrm{SO}_{2}$ & $\mathrm{PM}_{10}$ & $\mathrm{SO}_{2}$ & $\mathrm{PM}_{10}$ & $\mathrm{SO}_{2}$ & $\mathrm{PM}_{10}$ & $\mathrm{SO}_{2}$ & $\mathrm{PM}_{10}$ \\
\hline Ankara & 170 & 103 & 125 & 83 & 163 & 100 & 72 & 80 \\
\hline Bursa & 185 & 89 & 224 & 101 & 181 & 78 & 133 & 47 \\
\hline Erzurum & 145 & 87 & 176 & 98 & 189 & 129 & 276 & 159 \\
\hline Istanbul & 241 & 118 & 284 & 131 & 247 & 92 & 204 & 87 \\
\hline Izmir & 96 & 77 & 92 & 81 & 162 & 148 & 141 & 100 \\
\hline Kayseri & 161 & 79 & 141 & 74 & 149 & 66 & 182 & 139 \\
\hline Sivas & 260 & 144 & 193 & 169 & 197 & 145 & 269 & 156 \\
\hline WHO guideline & 50 & 70 & 50 & 70 & 50 & 70 & 50 & 70 \\
\hline
\end{tabular}

Bursa, Istanbul, and Izmir. These are also the cities where the majority of the manufacturing industries are concentrated (Table 1) (SYT 1994, AMIS 1990). Istanbul, with about 7 million people, supported $42.35 \%$ of the manufacturing industries in 1990. The industries in Istanbul mostly concentrated on metal, equipment, and textile production. Izmir and Bursa supported $10.1 \%$ and $5.26 \%$ of the total industrial activities, respectively. These activities were characterized by textile, food, beverage, and tobacco production. Erzurum and Sivas, with their respective shares of $1.4 \%$ and $0.2 \%$ of industrial activities, were minor contributors to industrial production.

Air pollution has been monitored in Turkey since 1980. The $\mathrm{SO}_{2}$ and particulate matter $\mathrm{PM}_{10}$ levels are measured daily in the major towns (SYT 1994). In all cities the levels of $\mathrm{SO}_{2}$ and $\mathrm{PM}_{10}$ exceeded the WHO guidelines in all the years between 1990 and 1993. The WHO ambient air-quality guideline for annual averages are: $70 \mu \mathrm{g} / \mathrm{m}^{3}$ for $\mathrm{PM}_{10}$ and $50 \mu \mathrm{g} / \mathrm{m}^{3}$ for $\mathrm{SO}_{2}$. The annual average air pollution measured in the major cities of Turkey is depicted in Table 2.

$\mathrm{O} n$ average, the highest level of $\mathrm{SO}_{2}$ was measured in Sivas and Istanbul and $\mathrm{PM}_{10}$ in Sivas and Erzurum during the 1990-1993 period. In Sivas and Erzurum the population is approximatelly 400,000 and the industrial activities are low (Table 1). The low-quality coal, highsulfur-content local lignite, petroleum, wood, and dried dung consumption in the households and transportation seem to be responsible for the high $\mathrm{PM}_{10}$ and $\mathrm{SO}_{2}$ levels (Table 3). In Istanbul not only the population size but also the industrial activities are the highest, hence both the low-quality coal used in households and the fossil fuel consumed in the industrial sectors contribute to the air pollution (Table 1-3) .

The annual average $\mathrm{PM}_{10}$ ambient concentration depicted a decreasing trend only in Istanbul and Bursa between 1990 and 1993. The $\mathrm{PM}_{10}$ and $\mathrm{SO}_{2}$ pollution increased in Erzurum in the same period of time. Ankara, I zmir, Kayseri, and Sivas experienced a fluctuating pattern in the annual average $\mathrm{PM}_{10}$ ambient concentration. A similar fluctuating pattern was observed in the annual average $\mathrm{SO}_{2}$ ambient concentration in Ankara, Bursa, Istanbul, Kayseri, and Sivas between 1990 and 1993 (Table 2).

$\mathrm{H}$ igh concentrations of air pollutants in many developing countries lead to increased illness, particularly among individuals suffering from respiratory problems, 
Table 3. Municipalities by type of fuel for heating and the 56-100\% utilization ratio of fuel, 1990 and 1993

\begin{tabular}{|c|c|c|c|c|c|c|c|c|c|c|c|c|c|c|c|c|c|c|}
\hline & \multicolumn{2}{|c|}{ Total municipality } & \multicolumn{2}{|c|}{ Local lignite } & \multicolumn{2}{|c|}{ Imp. lignite } & \multicolumn{2}{|c|}{ Coke } & \multicolumn{2}{|c|}{ NG } & \multicolumn{2}{|c|}{ Gas } & \multicolumn{2}{|c|}{ Fuel oil } & \multicolumn{2}{|c|}{ Wood } & \multicolumn{2}{|c|}{ Dried dung } \\
\hline & 1990 & 1993 & 1990 & 1993 & 1990 & 1993 & 1990 & 1993 & 1990 & 1993 & 1990 & 1993 & 1990 & 1993 & 1990 & 1993 & 1990 & 1993 \\
\hline Ankara & 50 & 59 & 31 & 27 & 9 & 11 & 0 & - & 0 & 2 & 0 & - & 0 & - & 2 & 2 & 1 & 5 \\
\hline Bursa & 46 & 53 & 13 & 19 & 1 & 3 & 0 & - & 0 & 2 & 0 & - & 0 & - & 18 & 16 & 0 & - \\
\hline Erzurum & 32 & 39 & 9 & 5 & 0 & 4 & 2 & 1 & 0 & - & 0 & - & 1 & - & 4 & 7 & 7 & 3 \\
\hline Istanbul & 48 & 78 & 32 & 38 & 0 & 2 & 0 & 2 & 0 & 3 & 0 & - & 0 & 1 & 8 & 6 & 0 & - \\
\hline Izmir & 68 & 84 & 47 & 55 & 0 & 3 & 1 & 1 & 0 & - & 0 & - & 0 & - & 23 & 11 & 1 & 1 \\
\hline Kayseri & 59 & 62 & 14 & 7 & 0 & 8 & 2 & 6 & 0 & - & 0 & - & 0 & - & 4 & 4 & 6 & 11 \\
\hline Sivas & 37 & 37 & 17 & 19 & 0 & - & 0 & - & 0 & - & 0 & - & 0 & - & 1 & 3 & 0 & 2 \\
\hline
\end{tabular}

Imp., imported; NG, natural gas.

Source: SIS. Environmental Statistics, Municipality Solid Waste Statistics, 1991, pp. 763-776. SIS U npublished Statistics collected in 1994.

and cause premature death among the elderly ( $O$ stro 1994). The air pollutants of greatest concern are carbon monoxide, hydrocarbons, sulfur oxides, nitrogen oxides, suspended particulate matter, lead, and secondary pollutants such as ozone. Since only $\mathrm{PM}_{10}$ and $\mathrm{SO}_{2}$ are monitored systematically in Turkey, the health effects associated with these are assessed in the next section.

\section{Health Benefit Estimation}

Epidemologic studies provide dose-response relationships between ambient levels of $\mathrm{PM}_{10}$ and $\mathrm{SO}_{2}$ and health outcomes, including premature mortality (PreM), respiratory hospital admissions (RHA), emergency room visits (ERV), restricted activity days (RAD) for adults, lower respiratory illness (LRI) for children, asthma attacks, and chronic diseases. The studies, which have found statistically significant relationships between measures of $\mathrm{PM}_{10}$ and $\mathrm{SO}_{2}$ and these health effects have been conducted in several different cities and seasons and thus incorporated a wide range of climates and populations.

Studies linking $\mathrm{PM}_{10}$ to mortality indicated that a 10 $\mu \mathrm{g} / \mathrm{m}^{3}$ change in $\mathrm{PM}_{10}$ resulted in an increased PreM of $0.31 \%-1.49 \%$, with a mean value of $0.96 \%$ (O stro 1992 , 1993; Schwartz 1991; Pope 1992). Plagiannakos and Parker (1988) found a statistically significant relationship between the incidence of hospital admissions due to respiratory diseases (RHA) and ambient sulfate levels. Samet and others (1981) analyzed the relationship between ERV and air pollution levels. A regression analysis was performed and daily ERV were regressed on maximum temperature and each of the pollutants in separate runs. The study results indicated that the $\mathrm{PM}_{10}$ and $\mathrm{SO}_{2}$ coefficients were statistically significant and highly correlated to the daily ERV. Restricted activity days (RAD) include days spent in bed, days missed from work, and other days when activities are significantly restricted due to illness. Ostro (1983) identified a statistically significant relationship between $\mathrm{PM}_{10}$ level and RAD. The study of Dockery and others (1989) related $\mathrm{PM}_{10}$ and $\mathrm{SO}_{2}$ levels to chronic cough and bronchitis in children.

Furthermore, studies indicated that $\mathrm{SO}_{2}$, acting alone or as a surrogate for other sulfur-related species, is associated with increased risk of mortality (Derriennic 1989, Chinn 1989, Krzyzanowski 1982, H atzakis 1986). Studies that provide evidence of the $\mathrm{SO}_{2}$ effect on the respiratory system include Charpin and others (1988), Bates and Sizto (1983), Ponka (1990), Dodge (1985), and Schwartz and others (1988).

Ostro (1994) used these studies to generate doseresponse information and formulated the health impact of a pollutant as follows:

$$
d H_{i}=b_{i} * P O P_{i} * d A
$$

where $\mathrm{dH}_{\mathrm{i}}$ is the change in population risk of health effect $i ; b_{i}$ is the slope from the dose-response curve; $\mathrm{POP}_{i}$ is the population at risk of health effect $i$; $d A$ is the change in air pollution under consideration; and $i$ is the health effect, i.e., PM, RH A, ERV, RAD, and LRI.

Here, as in other studies, the same dose-response coefficients are adopted to assess the health impacts of $\mathrm{SO}_{2}$ and $\mathrm{PM}_{10}$ for the Turkish urban population. This study, like other similar studies on other countries, does not take individual defensive actions into account (i.e., immunization) and does not consider market losses associated with sickness such as pain and suffering.

\section{Health and Economic Costs-Results}

The health effects associated with the $\mathrm{PM}_{10}$ and $\mathrm{SO}_{2}$ abatement are computed based on the medium dose- 
Table 4. Estimated increment in annual health effects associated with unit change in $\mathrm{PM}_{10}$ and $\mathrm{SO}_{2}$ levels $\left(b_{i} \text { values }\right)^{\mathrm{a}}$

\begin{tabular}{|c|c|c|c|c|c|c|c|}
\hline & \multicolumn{5}{|c|}{$\mathrm{PM}_{10}\left(\mu \mathrm{g} / \mathrm{m}^{3}\right)$} & \multicolumn{2}{|c|}{$\mathrm{SO}_{2}\left(\mu \mathrm{g} / \mathrm{m}^{3}\right)$} \\
\hline & PreM/ 100,000 & $\mathrm{RH} A / 100,000$ & ERV/ 100,000 & RAD/ person & LRI/ child & PreM/ 100,000 & RS/ 1,000 children \\
\hline Low & 0.45 & 0.66 & 12.83 & 0.040 & 0.0008 & 0.02 & 0.010 \\
\hline Medium & 0.67 & 1.2 & 23.54 & 0.058 & 0.0016 & 0.05 & 0.018 \\
\hline $\mathrm{High}$ & 0.91 & 1.56 & 34.25 & 0.090 & 0.0024 & 0.12 & 0.026 \\
\hline
\end{tabular}

Source: O stro (1994).

aPreM: premature mortality; RH A: respiratory hospital admission; RAD: restricted activity days; LRI: lower respiratoryillness; ERV: emergency room visits; RS: respiratory symptoms.

Table 5. Abatement levels of $\mathrm{SO}_{2}$ and $\mathrm{PM}_{10}$ needed to reach WHO guidelines $\left(\mu \mathrm{g} / \mathrm{m}^{3}\right)$

\begin{tabular}{lrrrrr}
\hline & \multicolumn{2}{c}{$1990(\mathrm{dA})$} & & \multicolumn{2}{c}{$1993(\mathrm{dA})$} \\
\cline { 2 - 3 } \cline { 5 - 6 } & $\mathrm{SO}_{2}$ & $\mathrm{PM}_{10}$ & & $\mathrm{SO}_{2}$ & $\mathrm{PM}_{10}$ \\
\hline Ankara & 120 & 33 & 22 & 10 \\
Bursa & 135 & 19 & 83 & - \\
Erzurum & 95 & 17 & 226 & 89 \\
Istanbul & 191 & 48 & & 154 & 17 \\
Izmir & 46 & 7 & 91 & 30 \\
Kayseri & 111 & 9 & 132 & 69 \\
Sivas & 210 & 74 & 219 & 86 \\
\hline
\end{tabular}

response coefficients $\left(b_{i}\right)$ depicted in Table 4 . The population at risk $\left(P O P_{i}\right)$ is reported in Table 1 . The abatement levels $(\mathrm{dA})$ that are needed to reach WHO guidelines are shown in Table 5.

The values of Table 5 are computed based on Table 2. For example, the ambient concentration of $\mathrm{SO}_{2}$ in Ankara in 1990 needed to be reduced by $120 \mu \mathrm{g} / \mathrm{m}^{3}$ ( $\mathrm{dA}=170-50)$ according to the WHO guideline. The levels of PreM, RHA, ERV, RAD, LRI, and respiratory symptoms (RS) are computed. The estimates of health effects achieved from reaching WHO guidelines for $\mathrm{PM}_{10}$ and $\mathrm{SO}_{2}$ levels are provided in Tables 6 and 7.

The results indicate that if annual $\mathrm{PM}_{10}$ were reduced to the WHO guideline $\left(70 \mu \mathrm{g} / \mathrm{m}^{3}\right)$ this could have reduced premature mortalities by 3317 and 3060 in 1990 and 1993, respectively. Furthermore, it could have reduced RHA by 5938 and 5481 and ERV by 121,412 and 112,162 in 1990 and 1993, respectively. While assessing RAD for employees 12 years old and above, the results show that the required abatement could have avoided 8.26 and 6.85 million working days Ioss. The LRI for children $0-12$ years old could have been decreased by 524,000 and 457,000 in 1990 and 1993, respectively.

Table 7 depicts the estimated health effects associ- ated with $\mathrm{SO}_{2}$ levels measured in 1990 and 1993. If the $\mathrm{SO}_{2}$ levels were reduced to the WHO guideline ( 50 $\left.\mu \mathrm{g} / \mathrm{m}^{3}\right)$, this could have brought a reduction of 993 and 900 cases of premature mortality and 7080 and 7130 respiratory symptoms among children age $0-12$ years in 1990 and 1993, respectively.

\section{Economic Evaluation and GDP Adjustment}

The direct annual loss of output caused by absenteeism arising from air pollution is computed by multiplying estimates of days lost in 1990 and 1993 due to sickness by the average daily wages. These average daily wages were 28,585 and 130,063 Turkish lira (TL) in urban areas for 1990 and 1993, respectively (SYT 1994). To attach an economic value to RHA, the annual average prices of doctors' fees were used (Table 8). The ERV fees were based on those of private hospitals, which were $167,640 \mathrm{TL} /$ visit/ person and 480,000 TL/ visit/ person in 1990 and 1993, respectively.

Information on doctors' fees in Bursa, Kayseri, and Sivas, were unavailable, so we used the closest city's prices: the Istanbul price was used for Bursa, and the Erzurum price was used for Kayseri and Sivas.

The results indicate that a decrease in $\mathrm{PM}_{10}$ and $\mathrm{SO}_{2}$ levels to WHO guidelines would have resulted in a total of $48.303 \times 10^{10} \mathrm{TL}$ and $153.38 \times 10^{10} \mathrm{TL}$ savings in 1990 and 1993, respectively (Table 9). The health cost is estimated to be $0.12 \%$ and $0.08 \%$ of 1990 and 1993 GDP, respectively. This is rather low when compared to the health costs estimated for the UK ( $1 \%$ of GNP) in 1993 (Pearce 1996). However, these study results were based not only on morbidity costs but also on mortality cost. Therefore, the results are not fully comparable.

In the early 1990s, the United Nations Statistical O ffice (UNSTAT) developed a framework for preparing 
Table 6. Estimated total health effects associated with $\mathrm{PM}_{10}$ level reduction to WHO guidelines in 1990 and $1993^{a}$

\begin{tabular}{|c|c|c|c|c|c|c|c|c|c|c|}
\hline & \multicolumn{2}{|c|}{ PreM } & \multicolumn{2}{|c|}{ RHA } & \multicolumn{2}{|c|}{ ERV } & \multicolumn{2}{|c|}{$\begin{array}{c}\text { RAD } \times 10^{6} \text { for employees } \\
12 \text { years and above }\end{array}$} & \multicolumn{2}{|c|}{$\mathrm{LRI} \times 10^{3} 0-12$ years } \\
\hline & 1990 & 1993 & 1990 & 1993 & 1990 & 1993 & 1990 & 1993 & 1990 & 1993 \\
\hline Ankara & 608 & 135 & 1,087 & 243 & 22,231 & 4,975 & 1.42 & 0.33 & 107 & 21 \\
\hline Bursa & 118 & - & 212 & - & 4,328 & - & 0.29 & - & 19 & - \\
\hline Erzurum & 69 & 602 & 123 & 1,079 & 2,517 & 22,053 & 0.11 & 1.02 & 10 & 88 \\
\hline Istanbul & 2,106 & 735 & 3,771 & 1,316 & 77,110 & 26,951 & 0.56 & 2.00 & 334 & 119 \\
\hline Izmir & 36 & 564 & 65 & 1,010 & 1,320 & 20,679 & 0.10 & 1.54 & 0.00 & 81 \\
\hline Kayseri & 25 & 504 & 45 & 902 & 921 & 18,459 & 0.05 & 1.03 & 0.00 & 75 \\
\hline Sivas & 355 & 520 & 635 & 931 & 12,985 & 19,045 & 0.62 & 0.92 & 54 & 73 \\
\hline Total & 3,317 & 3,060 & 5,938 & 5,481 & 121,412 & 112,162 & 8.26 & 6.85 & 524 & 457 \\
\hline
\end{tabular}

aPreM : premature mortality; RH A: respiratory hospital admission; RAD: restricted activity days; LRI: lower respiratoryillness; ERV: emergency room visits.

Table 7. Estimated total health effects associated with $\mathrm{SO}_{2}$ level reduction to $\mathrm{WHO}$ guidelines in 1990 and 1993

\begin{tabular}{|c|c|c|c|c|}
\hline & \multicolumn{2}{|c|}{ Premature mortality } & \multicolumn{2}{|c|}{$\begin{array}{l}\text { Respiratory symptoms for } \\
\text { children of age } 0 \text { - } 12 \text { years }\end{array}$} \\
\hline & 1990 & 1993 & 1990 & 1993 \\
\hline Ankara & 163 & 34 & 1,226 & 225 \\
\hline Bursa & 75 & 53 & 816 & 577 \\
\hline Erzurum & 18 & 50 & 356 & 974 \\
\hline Istanbul & 619 & 574 & 3,483 & 3,229 \\
\hline Izmir & 47 & 107 & 54 & 844 \\
\hline Kayseri & 32 & 44 & 410 & 561 \\
\hline Sivas & 39 & 38 & 736 & 722 \\
\hline Total & 993 & 900 & 7,084 & 7,132 \\
\hline
\end{tabular}

Table 8. Doctors' fees per person (annual average nominal prices, $\mathrm{TL})$

\begin{tabular}{lcc}
\hline & 1990 & 1993 \\
\hline Ankara & 53,646 & 161,979 \\
Bursa & NA & NA \\
Erzurum & 21,264 & 150,625 \\
Istanbul & 44,118 & 94,479 \\
Izmir & 41,256 & 92,474 \\
Kayseri & NA & NA \\
Sivas & NA & NA \\
\hline
\end{tabular}

Source: SYT (1994, p. 590).

a system of integrated environmental and economic accounts (SEEA). A preliminary version of the framework was tested in M exico and Papua New Guinea (Lutz 1993). Depreciation of man-made, natural, social, and human capital was also covered in several other studies (Anielski 1992, Grobecker and Weber 1993, Repetto and others 1989, de Haan 1993). This study follows the framework suggested in the work of Adger and Whitby (1993). Hence, the GDP figures of 1990 and 1993 should be adjusted by the computed social costs occurred due to air pollution (Table 10).

\section{Summary}

Health benefits and economic costs of air-quality improvement were estimated. The computations are based on the dose-response coefficients established in several studies. The average annual ambient concentrations of $\mathrm{PM}_{10}$ and $\mathrm{SO}_{2}$ were above the WHO guidelines in the major towns of Turkey between 1990 and 1993. The estimated health effects, which could have been avoided with decreased $\mathrm{PM}_{10}$ and $\mathrm{SO}_{2}$ levels, were $4.3 \times$ $10^{3}$ and $3.9 \times 10^{3}$ cases of premature mortality, $5.9 \times$ $10^{3}$ and $5.4 \times 10^{3}$ cases of respiratory hospital admissions, $121.4 \times 10^{3}$ and $112.1 \times 10^{3}$ emergency room visits, $8.26 \times 10^{6}$ and $6.86 \times 10^{6}$ restricted activity days for workers, and $53.1 \times 10^{3}$ and $46.4 \times 10^{3}$ cases of lower respiratory illness for children in 1990 and 1993 respectively. This would have resulted in a total of $48.57 \times 10^{10} \mathrm{TL}$ and $154.08 \times 10^{10} \mathrm{TL}$ savings in 1990 and 1993 , respectively, which are $0.12 \%$ and $0.08 \%$ of 1990 and 1993 GDP, respectively. Finally, these health costs are applied for the adjustment of the 1990 and 1993 GDPs. These estimated costs are lower compared with the UK study, in which both the morbidity and mortality costs are estimated. The complete GDP adjustment will still require estimation of the total economic value of the natural resources and environmental services existing in Turkey that support the economic activity of the country. Hence, besides the health 
Table 9. Estimated economic cost associated with $\mathrm{PM}_{10}$ and $\mathrm{SO}_{2}$ level reduction to $\mathrm{WHO}$ guidelines in 1990 and 1993

\begin{tabular}{|c|c|c|c|c|c|c|}
\hline & \multicolumn{2}{|c|}{ RAD $\left(\times 10^{10} \mathrm{TL}\right)$} & \multicolumn{2}{|c|}{ RHA and ERV $\left(\times 10^{6} \mathrm{TL}\right)$} & \multicolumn{2}{|c|}{$\begin{array}{l}\text { Respiratory symptoms for children } \\
\text { of age } 0-12 \text { years }\left(\times 10^{6} \mathrm{TL}\right)\end{array}$} \\
\hline & 1990 & 1993 & 1990 & 1993 & 1990 & 1993 \\
\hline Ankara & 1.20 & 1.01 & $3,321.1$ & $2,244.5$ & 65.77 & 36.44 \\
\hline Bursa & 1.48 & - & 379.2 & - & 43.77 & 93.46 \\
\hline Erzurum & 0.37 & 13.50 & 200.1 & $5,302.5$ & 7.57 & 146.71 \\
\hline Istanbul & 40.57 & 60.07 & $12,136.96$ & $12,801.6$ & 153.66 & 305.07 \\
\hline Izmir & 0.57 & 36.05 & 178.75 & $8,452.9$ & 2.22 & 78.04 \\
\hline Kayseri & 0.26 & 22.05 & 100.6 & $6,093.3$ & 8.71 & 84.50 \\
\hline Sivas & 2.12 & 13.15 & $1,097.9$ & $39,746.2$ & 15.65 & 108.75 \\
\hline Total & 46.54 & 145.83 & $17,414.63$ & $74,640.9$ & 297.35 & 852.95 \\
\hline
\end{tabular}

Table 10. Modified national accounts at 1990 prices (billion TL)

\begin{tabular}{lcc}
\hline & 1990 & 1993 \\
\hline Agriculture & 65,717 & 66,890 \\
Industry & 83,333 & 114,690 \\
Services & 210,099 & 242,378 \\
Social costs due to & & \\
RAD & -0.46 & -0.36 \\
RH A and ERV & -0.17 & -0.02 \\
RS & -0.003 & -0.0002 \\
GDP (at factor cost) & 359,149 & 423,958 \\
Modified GDP (at factor cost) & $359,148.3$ & $423,957.6$ \\
\hline
\end{tabular}

Source: Main Economic Indicators, 1995. General Directorate of Economic Research and Assessment, Ankara-Turkey.

costs, pollution abatement and other damage costs should be accounted for together with the economic value of environmental ser vices supporting the Turkish economy.

\section{Literature Cited}

Adger, W. N., and M. Whitby. 1993. National resource accounting in the land-use sector: Theory and practice in Europe. Review of Agricultural Economics 20:77-97.

Anielski, M. 1992. Resource accounting: Indicators of the sustainability of Alberta's forest resources. Paper presented to the International Society of Ecological Economics Conference, Stockholm.

AMIS (Annual Manufacturing Industry Statistics). 1990. State Institute of Statistics, Prime Ministry, Republic of Turkey, Ankara.

Bates, D. V., and R. Sizto. 1983. Air pollution and hospital admissions in southern Ontario: The acid haze effect. Environmental Resources 43:317-331.

Berkes, F., and C. Folke. 1992. A system perspective on the interrelations between natural, human-made and cultural capital. Ecological Econ omics 5:1-8.
Charpin, D., J. P. Kleisbauer, J. Fondarai, P. Graland, A. Viala, and F. Gouezo. 1988. Respiratory symptoms and air pollution changes in children: The Gardanne coal-basin study. A rchives of Environ mental $\mathrm{H}$ ealth 43:22-27.

Chinn, S. V., I. Florey, G. Baldwin, and M. Gorgol. 1989. The relation of mortality in England and Wales 1969-73 to measurements of air pollution. Journal of E pidemi ology Community $\mathrm{H}$ ealth 35:174-179.

de $\mathrm{H}$ aan, M., S. J. Keunin, and P. Bosch. 1993. Integrating indicatorsin a national accounting matrix including environmental accounts (NAMEA). NA 060. Central Bureau of Statistics, Voorburg.

Derriennic, F., S. Richardson, A. Mollie, and J. Lellouch. 1989. Short-term effects of sulfur dioxide pollution on mortality in two French cities. International Journal of Epidemiology 18:186280.

Docker y, D. W., F. E. Speizer, and D. O. Stram. 1989. Effects of inhalable particles on respiratory health of children. American Review of Respiratory Diseases 139:587-597.

Dodge, R., P. Solomon, J. Moyers, and C. Hayes. 1985. A longitudinal study of children exposed to sulfur oxides. A merican Journal of Epidemiology 121:720-736.

Hatzakis, A., K. Katsouyanni, A. Kalandidi, N. Day, and D. Trichopoulos. 1986. Short-term effects of air pollution on mortality in Athens. International Journal of Epidemiology 15:73-81.

Krzyzanowski, M., and B. Wojtyniak. 1982. Ten-year mortality in sample of an adult population in relation to air pollution. Journal of Epidemiology and Community $\mathrm{H}$ ealth 36:262-268.

Grobecker, C., and J.-L. Weber. 1993. La place de la compatibilité du patrimoine naturel dans les travaux de l'institut français de l'environnement, cinqueième colloque de compatibilité nationale de l'Association de Compatiblité Nationale, Paris, 13-15 Decembre.

Lutz, E. (ed). 1993. Toward improved accounting for the environment. The World Bank, Washington, DC.

Ostro, B. 1983. The effects of air pollution on work loss and morbidity. Journal of Environmental Economics and Manage ment 10:371-382.

Ostro, B. 1992. Environmental pollution and health. Lancet 340:1220-1221. 
O stro, B. 1993. The association of air pollution with mortality: Examining the case for inference. Archives of Environmental $H$ ealth 48:336-342.

Ostro, B. 1994. Estimating the health effects of air pollutants: A method with an application to Jakarta. Policy research working paper 1301. The World Bank, Washington, DC.

Pearce, D. W. 1993. Economic values and the natural world. MIT Press, Cambridge, Massachusetts.

Pearce, D. W. 1996. Economic valuation and health damage from air pollution in the developing world. Energy Policy 24( 7) :627-630.

Plagiannakos, T., and J. Parker. 1988. An assessment of air pollution effects on human health in Ontario. Ontario $\mathrm{H}$ ydrology $\mathrm{M}$ arch.

Ponka, A. 1990. Absenteeism and respiratory disease among children and adults in Helsinki in relation to low-level air pollution and temperature. Environmental Resources 52: 34-46.
Pope, C. A., J. Schwartz, and M. Ransom. 1992. Daily Mortality and PM 10 pollution in U tah Valley. Archives of Environmental $H$ ealth 42:211-217.

Repetto, R., W. Magrath, M. Wells, C. Beer, and F. Rossini. 1989. Wasting assets: Natural resources in the national accounts. World Resources Institute, Washington, DC.

Samet, J. M., Y. Bishop, F. E. Speizer, J. D. Spengler, and B. G. Ferris. 1981. The relationship between air pollution and emergency room visits in an industrial community. Journal of the Air Pollution Control Association 31:236-240.

Schwartz, J. 1991. Particulate air pollution and daily mortality in Detroit. Environmental Resources 56:204-213.

Schwartz, J., V. H asselblad, and H. Pitcher. 1988. Air pollution and morbidity: A further analysis of the Los Angeles student nurses data. Journal of the Air Pollution Control Association 38:158-162.

SYT (Statistic Yearbook of Turkey). 1994. State Institute of Statistics, Prime Ministry, Republic of Turkey, Ankara. 